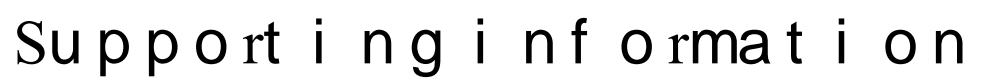

\title{
Probing the Origin of Light Enhanced Ion Diffusion in Halide Perovskites
}

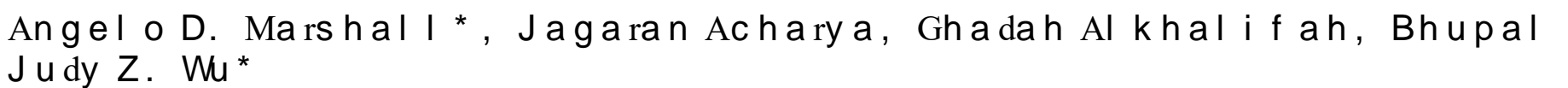

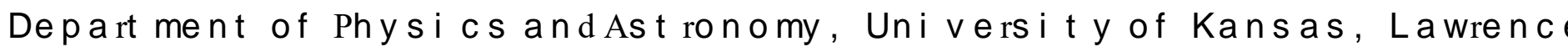

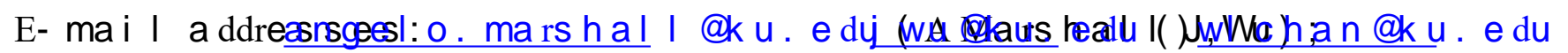



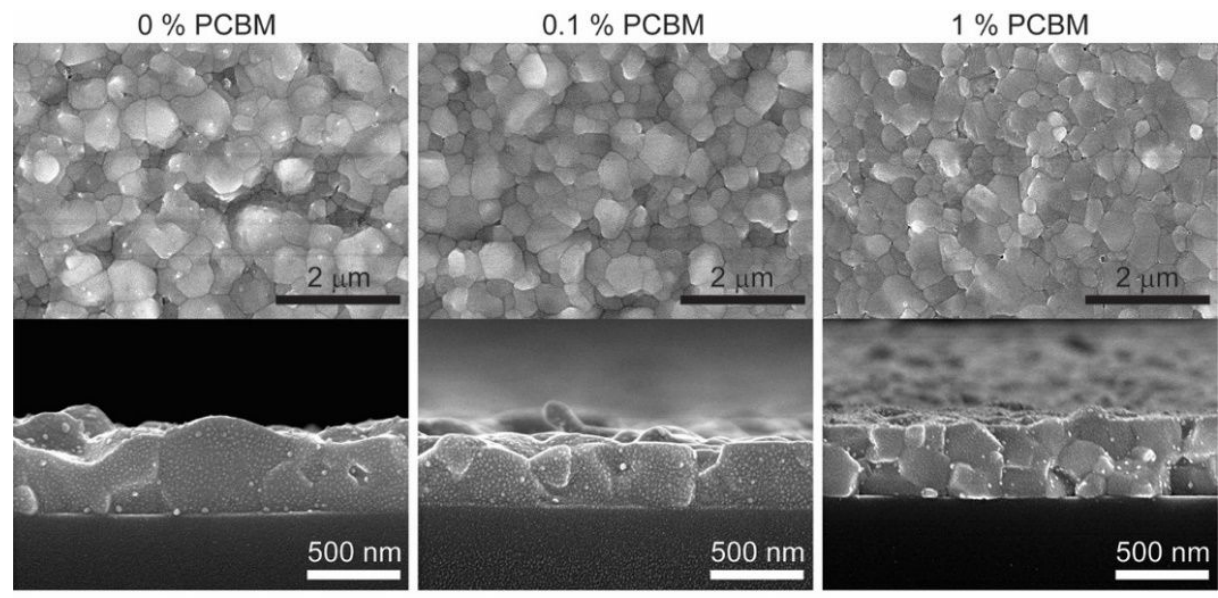

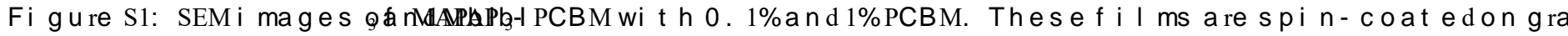

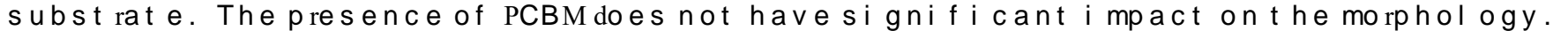
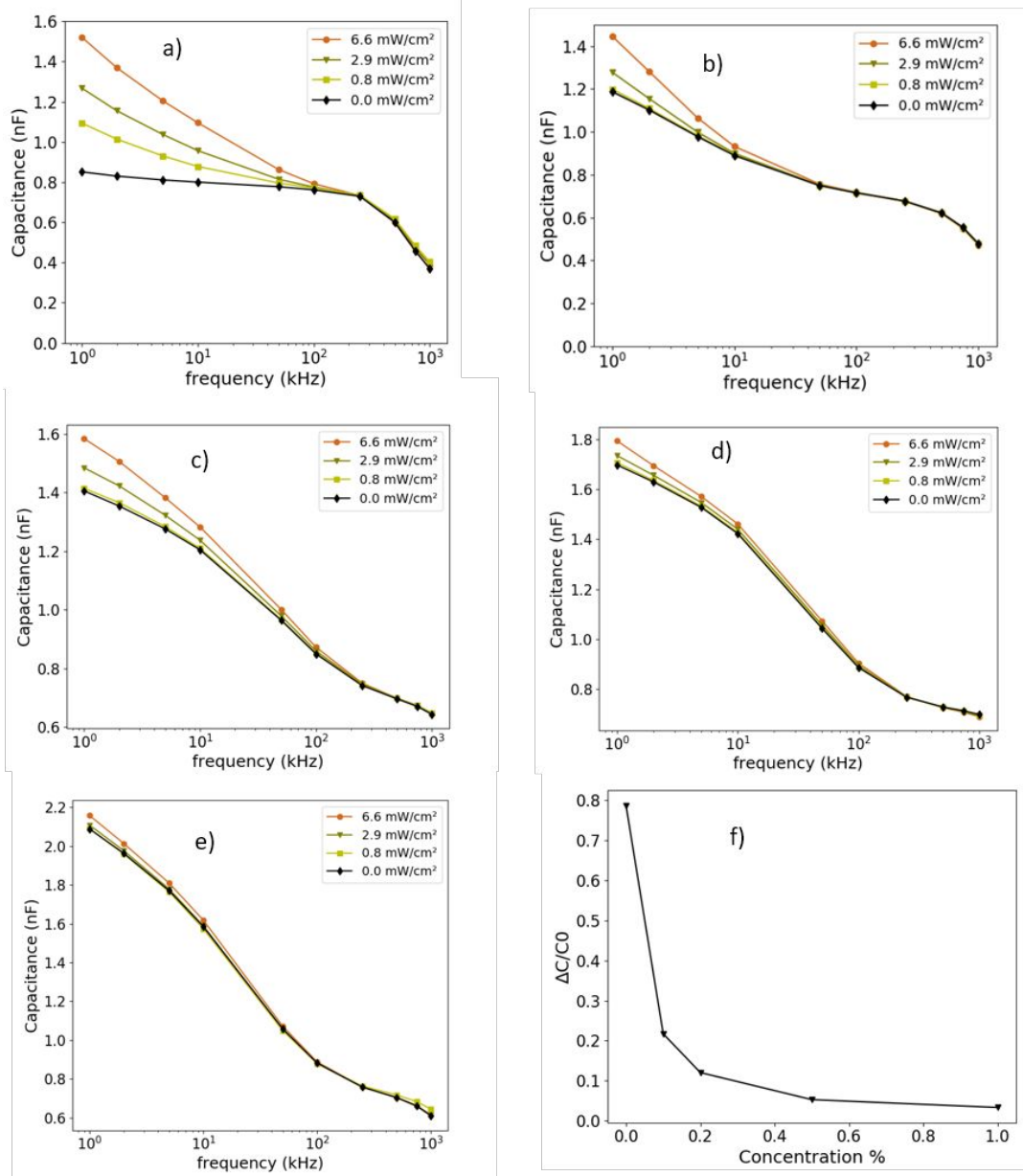

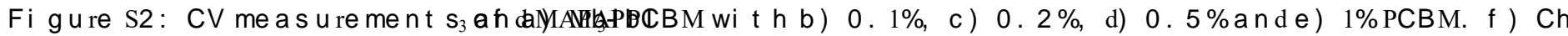

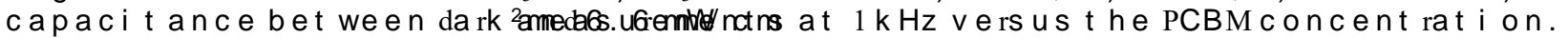

